\title{
THE KUNSTWOLLEN OF THE SCIENTIFIC ERA AND ALOIS RIEGL'S STIMMUNG
}

\section{Essay}

\section{Konstantinos Vassiliou}

\begin{abstract}
Alois Riegl's essay "Die Stimmung als Inhalt der modernen Kunst" (1899) has been one of art historiography's early attempts to bridge art and science. In this text, Riegl not only presents the background of some of his theoretical and methodological premises but he also provides an overarching argument for the way natural sciences affect modern spectatorship. In this way, he establishes the basis of a Kunstwollen for the 'age of the natural sciences' and describes its appropriate artistic traits. Addressing the intellectual and historical context of the Stimmung Essay, this article shows how Riegl's ideas work in a subtle and intricate manner, involving the combination of sensual and phenomenological observations to modes of knowledge. In this respect, the relation of art and science does not seem to be settled on a fixed contemplative basis but on the combination of the art with cognition and affects.
\end{abstract}

KEYWORDS

Alois Riegl, Art and Science, Tactile, Optic, Kunstwollen

Since the 1960s, there has been developed an impressive quantity of scholarship about the relationship of art and the natural sciences, focused mainly on art and technology. Yet an analysis which highlights deeper common schematisations and thought processes in art and science is still in a precarious state. The art historian Martin Kemp has recently managed to break down several facets of this problem in his description of cases of structural intuitions. ${ }^{1}$ In this respect it seems quite important that in a much earlier phase of art historiography, Alois Riegl tried significantly to theorise art's social role precisely against the background of the salient if not dominant social role of the natural sciences. Riegl's thought on this matter is clearly explicated in his short essay called "Die Stimmung als Inhalt der modernen Kunst”, ${ }^{2}$ a text that is yet to receive due attention within the growing scholarship surrounding the Austrian art historian's work. ${ }^{3}$ Published in the journal Die 
graphischen Künste, the essay was written during a period of aesthetic debates regarding modern art in Vienna, ${ }^{4}$ yet its scope extends far beyond these localised exchanges. Clearly written to appeal to a wider audience, the essay is specifically focused on the relation of art and science, seeking to redefine a broader theory of modern art.

The eponymous notion, namely the German term Stimmung, has a complex philological history across various languages, originating in Ancient Greek and Latin, and it is a term that has proved notoriously difficult to adequately translate. ${ }^{5}$ Furthermore, this concept has featured in a considerable number of Riegl's writings. 6 In what follows, however, this paper is not mainly concerned with an analysis of Riegl's treatment of this concept. Rather, it focuses on Riegl's attempt to decipher an appropriate Kunstwollen for, as he calls it, the age of natural sciences. In this respect, his essay seems to reconceptualise art's place within modern spectatorship - an issue which early art historiography has not frequently tackled.

\section{SENSES AND MORALITY}

Riegl begins the essay with an introduction to an analytical pair that was of crucial importance throughout his work: namely distant and close vision (Fernsicht, Nahsicht), and the concomitant optic-tactile distinction. ${ }^{7}$ The very start of the text is an attempt to engage in a phenomenological study of spectatorship. The initial paragraphs are written in first person as Riegl narrates a (probably fictional) personal experience. The recounted scene takes place at the peak of a remote mountain in the Alps. A 'lonely observer' is sitting at the precipice of a cliff-edge. There is no stimulus to engage his sense of touch (Tastsinn), whereas his sight or gaze is activated while he absorbs the entire valley, as far as his visual field extends. Riegl explains that as the observer overlooks the whole, what he discerns is in fact an antithetical schema. Because although he sees signs everywhere that attest to "restless life, endless power and incessant movement," the very ability to encompass all of this generates in the observer a feeling of "unifying calmness." 8 According to Riegl, this antithesis bears testimony to the moral constitution of the modern spectatorship:

What the soul of the modern man consciously or unconsciously longs for is the very thing that is fulfilled in this lonely observer in that mountain peak. It is not the peace of the cemetery that surrounds him but he sees the manifold life sprouting up what seems to him in close range as merciless fight, seems from long 
range a peaceful coexistence, concordance and harmony.... We designate this presentiment of order and lawfulness over the chaos, of harmony over dissonances, of calmness over movements as Stimmung. Its elements are calmness and distant vision (Fernsicht). ${ }^{9}$

The Stimmung vanishes at the moment when the observer is interrupted in his contemplation by certain stimuli; in this case, as Riegl informs us, by the unexpected presence of a goat or a bird which distract and excite the observer who wants to avoid or grab them. The result is that he is "once again thrown into the struggle for existence." 10 According to Riegl, Stimmung disappears precisely when someone re-immerses into life-stimuli, in what Riegl calls close vision (Nahsicht) which is full of impulses (Regungen). Riegl claims that this antithesis of Stimmung to stimulation can be found not only in contemplation of grand mountainous landscapes; instead, it can be experienced anywhere so long as two conditions are met: 1) a withdrawal of the observer from the stimuli, and 2) the withdrawal from the bustling activity of the life-struggle seen throughout nature. Contemplation of a vast seascape, for example, is equally capable of stimulating such an experience. ${ }^{11}$ This withdrawal is linked specifically to distant and optic vision, as opposed to close vision and tactility.

In the Stimmung Essay, Riegl does in fact trace a link between tactile vision and the actual sense of touch, since the stimuli of the world that distract the observer from the feeling of Stimmung are indeed real stimuli that provoke a kinaesthetic response. In this sense, he introduces the distinction according to an embodied aesthetic phenomenology. So Riegl's essay revolves around a different mode of tactility than his later writings, which despite its varied meanings and nuances will be mainly centred on the arrangements between forms and their background. The observer oscillates between poles of an optic/distant and tactile/close vision, and the tactile is here anchored on a kinaesthetic process, a movement of the environment, which arises in real interaction with the natural realm.

This implies an identification of stimulation with tactility. This kind of understanding is not out of place in nineteenth-century scientific research. Applied psychology in the German-speaking world rendered touch to be the primary vehicle for addressing human responsiveness, 12 and in this respect the tactile was not limited to a specific sensation; rather, it was to be understood as a pattern of reflexive behaviour. Riegl's phenomenological premises 
here are not highly original and they are sufficiently rooted in the intellectual climate of the nineteenth-century German applied aesthetics - shaped by Immanuel Kant, Johann Friedrich Herbart, Gustav Fechner, Wilhelm Wundt, and in Riegl's time Theodor Lipps.

Nevertheless, as usually is the case in Riegl, his argument runs more as a broad synthesis and mitigation of parallel and sometimes antithetical theories than as a break from them. So these remarks on tactility seem important not only as a special case in the work of Riegl, where he proceeds to define a more embodied version of the tactile, but also because they introduce us to the moral background for his argument that deals with the role of art in modernity. In this respect, the most potent part of the essay is when he develops this initial and rather phenomenological analysis in order to describe the relation between art and science.

\section{SCIENCE AND THE MODERN SPECTATOR}

For Riegl it is of primary importance that the modern spectator knows how the natural world works. The burden (Drückende) that his observer initially feels when faced with the multiplicity of things was clearly elicited by "our knowledge, the ripe fruit of the Tree of Knowledge."13 In another example, describing one's contemplation of the vast sea, Riegl characterises the unending and seemingly meaningless breaking of the waves as "the clear reflection of the cosmic driving force in close vision." 14

One may spot here a certain Schopenhauerian note in Riegl's reasoning. Indeed, his concept of Stimmung is similar to Schopenhauer's idea of the sublime, developed in light of Kant's formulation. Schopenhauer says explicitly that there is a "Stimmung which provokes the feeling of the sublime"; 15 the converse being, as in Riegl, the notion of stimulation (Reiz). ${ }^{16}$ But nonetheless, there is a crucial point of difference. For the German philosopher, causality and science are bound to be a fruitless endeavour governed by the tyranny of the Will, which tends to organise any representation. Thus in scientific knowledge, according to Schopenhauer, we "can no more find a final goal or complete satisfaction than we can walk to the point where the clouds touch the horizon." 17 On the contrary, for Riegl the very reason that distant vision is appealing is that it allows the integration of a whole chain of causality within a single impression or gaze. As he explains, this has an impact on modern art as such:

As our modern knowledge does not observe the natural phenomena in their isolation - as did the pagan antiquity and 
the Christian Middle-Ages, as individual exteriorizations of a personal deity - but in their causal association with their closer and more distant environment: modern art proceeds in the same manner in its record of natural impressions, which it cannot supersede but which it also recreates by its own peculiar means. So it becomes above all understood, that the modern need for Stimmung can be satisfied and pleased in a full and direct manner only through a [kind of] painting based upon pure optic record [Aufnahme] and grounded on distant-vision. ${ }^{18}$

This kind of fusion of Schopenhauerian ideas and the value of natural sciences exemplifies Riegl's synthetic approach. But these are not by far Riegl's points of reference, since he reframes this problem of art and knowledge to a historical schema that also bears clear echoes from Hegel. Indeed Riegl argues that there are three main stages in the development of the arts. The first, which he considers primitive, is characterised by the struggle of all against all, a struggle that is mitigated by the appearance of the totem. The second, predominant in antiquity, is based on the rule by the strong, and it reaches its climax during the Roman Empire. The third begins with the advent of Christianity, and seeks harmony not in a physical object or being but rather in a divine ethical entity. ${ }^{19}$ Across all of these stages, Riegl further develops the underlying motifs of each period (the totem, the body for antiquity, the face for Christian art), and he states that in terms of coping with human needs the third phase was supreme. Yet the birth of the scientific age brought the third phase to an end, as the world came to be understood once again to be an arena of uncontrollable impulses and powers. In that sense, the age of the natural sciences [Zeitalter der Naturwissenschaften] inaugurates a fourth period, and consequently a novel worldview in which we see a distinct barrier between the causality of natural phenomena and the irrational natural forces. Riegl claims that Stimmung appears at the moment when the laws of causality, as determined by the natural sciences, suggest an internal harmony that overcomes the tension introduced by their conflicting and swarming coexistence.

The argument presented above is germane to Riegl's championing of modern landscape painting. Indeed, Riegl thought that the preeminent type of art that provokes Stimmung is landscape painting. In the essay he includes some pictures of paintings to showcase the art of the Stimmung. Riegl, however, appears to be apologetic for the pictures, stating that they were drawn from the stock of images owned by the journal (Die 
graphischen Künste) and that, in truth, these would not be his ideal choice from among the canvases composed by modern artists. ${ }^{20}$ Furthermore, he poses the question whether a painting that has fictional or fantasy elements is appropriate or not for art in the age of the natural sciences. Riegl's response is affirmative. Fantastic creations should "convince us, that if the same [creatures] existed, they would have to look and behave that way and not in another." ${ }^{21}$ Riegl cites Arnold Böcklin, Hans Toma, and Max Klinger as successful painters in this regard.

Of course landscape painting was traditionally rather low in the hierarchy of pictorial genres yet its designation as the highest in Riegl's era was hardly an original insight. The aesthetics of Romanticism afforded a prominent role to natural beauty, which of course remained the main source of romantic Stimmung. Hegel argued furthermore that since any "work of art stands higher than any natural product" this also means that painted landscapes are "in higher rank than the mere natural landscape." 22 All these prompted the German-speaking world to make several theoretical attempts to accord to landscape painting the primacy of genre hierarchy. Notable were Carl Gustav Carus' Briefe über Landschaftsmalerei (1831) and Richard Wagner's Das Kunstwerk der Zukunft (1849). Carus likewise linked landscape painting explicitly with the notion of Stimmung. ${ }^{23}$ Yet for Carus, "science and art are antithetical" because the first moves from multiplicity to unity whereas the latter operates in the converse manner. ${ }^{24}$

The very relation of landscape painting and science was directly evidenced in Kosmos by Alexander Humboldt (first volume appearing in 1845), probably one of the most widely circulated scientific texts in the nineteenth century. Humboldt presented an argument of striking similarity to that put forward by Riegl. Humboldt argued that, contrary to the views espoused by Edmund Burke, the development and increasing prominence of scientific observation of "great mutual relations of phenomena" 25 actually reinforces the feeling of the sublime; and in the second volume of his work, Humboldt devotes a whole chapter to the importance of landscape painting. ${ }^{26}$ In a way, Riegl's Stimmung is based on this reconstruction of the sublime as a specifically modern feeling fuelled by the scientific worldview and enhanced by the powerful scientific observations of the complexity of nature at both a grand and minute scale. Nevertheless, in contrast to the feeling of the sublime, that generates a feeling of incommensurability between the observer and what is represented in the observation, Riegl posited a reconciliation and harmonisation for modern spectatorship. So 
in contrast to the tumultuous emotions of romantic sublimity, Riegl reverts to Schopenhauer's idea that contemplation of nature has a soothing effect.

\section{THE KUNSTWOLLEN OF THE SCIENTIFIC ERA}

Riegl's argumentation in the Stimmung Essay is very similar to that which is used in his Historical Grammar of the Visual Arts. 27 The rather Hegelian schema, as described above, is developed further in this two-part manuscript, comprising a book and a full cycle of university lectures written between 1897-1899 - at exactly the same time as the Stimmung Essay - and published posthumously. In this work, Riegl's initial argument is that art is produced in competition (Wettschaffen) with nature. This competition is expressed in art as its "fluctuation between two poles":

... the harmonic, which strives to bring the immutable law of crystallinity to view in all motifs including the organic ones; and the organic whose supreme goal is to represent organic motifs in all their accidental and transitory momentary appearances. ${ }^{28}$

The distinction between crystallic and organic motifs, which via Worringer would have a lasting influence in art history, ${ }^{29}$ is here placed within the need for harmony. The Historical Grammar establishes thus a similar - but not identical - periodisation of art in order to describe how this strife for harmony is fulfilled. This involves three periods based on different Weltanschauungen. The first, which extends from Egyptian to Greco-Roman art, tends to mechanise nature, the second period, manifested in early Christian art, spiritualises nature, and the third, which begun after the Reformation, is predominantly natural-scientific because it aims to reproduce the individual and transitory appearances of nature. During this later period, there is a focus on individuated natural objects, ultimately meaning that humanity can no longer conceive of itself as a telos in the chain of the natural world; yet there remains a distinct desire for harmony and morality. As Riegl explains:

Strictly speaking matter, too, distinguishes not individuals but only a law; this was formulated in our own century as the Law of the Conservation of Energy. How does all this pertain to artistic production? Improvement of nature: our senses deceive us by showing individuals; there are no individuals. Threedimensionality must therefore be merely illusory; naturalscientific art must be anti-sculptural. It communicates the will of 
things mainly with optic vision.... What differentiates such art from nature? The relations among objects come more clearly to view in the image than in nature; there lies the improvement. ${ }^{30}$

This echoes the aforementioned Hegelian view for the superiority of art to nature and thus of landscape painting to mere natural landscape. Yet Riegl appears to be sceptical about any direct correlation between art and philosophy as such. The reason appears to be two-fold. Firstly, Riegl seems to think that philosophy has always been a scholarly endeavour that cannot easily be assimilated with art. ${ }^{31}$ Secondly, that the very concept of Kunstwollen was also an attempt to disconnect the history of art from its determination as the mere appendage of a Zeitgeist or the result of a rather linear progression. Panofsky had clearly described that role of the Kunstwollen. According to him the Kunstwollen should not be thought solely on the basis of an individualistic psychologism or a Zeitgeist but should be mainly deduced from the circumstantial complexities of forms, documents, and ideas which art tends to objectify. In this way, Panofsky argues, philosophy and art history can "secure a mode to stand side by side." 32

These views are evidenced in how Riegl connects Stimmung to art's materiality. In the same year that the Stimmung essay appeared in print, Riegl published another short text which was a critical presentation of a homonymous lecture of the publication of the German art historian Julius Lessing, titled "Das Moderne in der Kunst”, that discussed extensively new changes in art, especially in applied arts and architecture. ${ }^{33}$ In the text, Riegl praises the fact that Lessing acknowledges that the age of the natural sciences introduces a new artistic triptych: new material, new techniques, and new ends for the uses of art (Gebrauchszwecke). But against Lessing's technical and material determinism, largely influenced by Gottfried Semper, Riegl claims that these three parameters cannot fully explain stylistic trends. Again Riegl argues that the modern relationship with nature has been shaped by a "conviction for an unconditioned validity of causality" with an interest in "a full chain of causes and effects that we can oversee, as it were, at a distance." 34 For Riegl, this must deter modern artists from inscribing a strict pattern in their works, which may result in a certain disgruntlement - the term used here being Verstimmung, the spoiling of Stimmung. ${ }^{35}$

Riegl's conclusion in this text - built as a reaction against Semper-influenced theories - in truth seems more radical than that reached in his Stimmung Essay. For Riegl, the optic element in the 
age of natural sciences might well advance to a degree such that we will see a hostility against form [Formfeindlichkeit]; to some extent, this explains why painting becomes the predominant mode in providing harmony of existence, as opposed to the dramatic arts and "immaterial music which now has become just as popular [volksthümlich] as had been the tactual-material sculpture in antiquity." 36 This leads Riegl to fully reject sculpture in addition to composed motifs (meaning pattern making) in applied arts (componirte Muster) as art forms completely out of tune with the modern Kunstwollen.

\section{THE SPATIO-TEMPORALITY OF STIMMUNG}

Against the idea of art-for-art's sake, Riegl's idea of Stimmung goes some way as to reinstate the social role of art. This ground for Stimmung arises at the point where faith and knowledge come apart, a situation first evident in late antiquity and then widened further during and after the Renaissance. According to the Stimmung Essay, this process was adopted faster in Protestant countries, and as early as the seventeenth century we see in Holland a landscape painting "that is exclusively founded in calmness and distant vision." 37 When finally the separation of faith from knowledge triumphed in Catholic countries, too, then there was "nothing more in the way for the full breakthrough of the art of the Stimmung." 38

This is why, according to Riegl, there was a lack of new formal stylistic elements and instead artists tried to "draw from the existent stock of artistic monuments of previous centuries what could seem to address the more or less clearly felt needs of the Stimmung," evident for example in the taste for "Venetian existential painting." 39 This art of the Stimmung provides a replacement for the former religious devotion [Andacht] which is actually a religious Stimmung (religiöse Stimmung). ${ }^{40} \mathrm{Riegl}$ concludes his essay by stressing the need to morally enhance this "deeply excited age from a spiritual point of view," which may arise from out of the synthesis of the human sciences. ${ }^{41}$ To this end, the role of the artist is to "draw the last, the highest and the decisive benefit from the modern knowledge and thereby to bring relief, if not salvation, to a kind of era that is in need of consolation." 42

Of crucial importance for Riegl, art ought to maintain a social mission that can supersede mere scholarly issues pertaining to taste since he seems alarmed by the shifts in art's social positioning. To be sure, this was not without its problems, not least because it presupposed a complicated coupling of morality and science. As Margaret Olin notes: 
$[\mathrm{H}]$ is identification of Stimmung with science unavoidably contaminates the knowledge science acquires with subjectivity and relativity. Riegl stumbles into the very catastrophe he seeks to avoid: since progress cannot be regarded as simply the acquisition and comprehension of 'truth', history threatens to deteriorate into a relativistic voluntarism that determines 'knowledge' and creates comforting images of the world. ${ }^{43}$

Yet for Riegl this node of morality and spectatorship was not only a treasured thesis of modern philosophical thought since Kant and Hegel. It was also to be observed in the responses of modern spectatorship to the challenges of new scientific knowledge. This is evidenced in his link between Stimmung to another key notion, namely age-value (Alterswert).

In a short essay about the restoration of the central portal of the St Stephan Cathedral in Vienna, Riegl claims that the very age of the monument bestows a Stimmungswert (Stimmung-value), which is characteristically a modern mode of observation and, as expected, he maintains that this Stimmung value is largely sensed "from a distance." 44 Moreover, in his better-known text on the "Modern Cult of Monuments" he will associate Stimmung with the very contemplation of time and history. ${ }^{45}$ Indeed, what Riegl defines in the Stimmung Essay as mainly a spatial experience, based on distant vision capable of constituting a chain of natural phenomena, corresponds to a temporal experience of nature in his concept of age-value. Age-value is something characteristically modern, which may "trigger a sense [Stimmungswirkung] of life cycle, of the emergence of the particular from the general and its gradual but inevitable dissolution back into the general." ${ }^{46}$ In the age of the Baroque, Riegl argues, the representations of ruins were built on a contrast between ancient greatness and present decline, a contrast which is alien for the modern audience for whom the "traces of age strike as testimony inevitably governed by natural laws that govern all artefacts." 47

So age-value corresponds to a state of mind influenced by the natural sciences, since "[in the] twentieth century we appreciate particularly the purely natural cycle of becoming and passing away." 48 In this respect, the "signs of violent destruction in the ruins of a castle are a relatively poor example for the evocation [Stimmung] of age-value for the modern viewer," 49 because - in quasi verbatim translation - it is not able "to provide complete salvation to the modern man of the Stimmung." 50 
In this sense, Stimmung becomes a mediating notion between the production of modern art and the reception of past art. Riegl further stresses that age-value is becoming a dominant category as the experience of the aesthetic becomes increasingly open to the masses. This is because age-value is sensed directly without the mediation of historical knowledge or stylistic criteria. Riegl acknowledges that this is a major driving force, "it gains followers by the day" whereas its supporters claim that "there is no aesthetic salvation except in Age-value." 51 In this respect, it is evident that for Riegl aesthetic notions such as Stimmung and age-value are not limited to the avid art lover. They become part of a more general response of modern spectatorship at large to the heteroclite intricacies of modern representations.

This doubling up of Stimmung as spatial and temporal experience clearly inscribes spectatorship within a complex web of thought. Hence Riegl's claim that the role of art in the era of the natural sciences is not to be limited to the subject-matter of painting or to a stylistic suggestion. Riegl's originality as a thinker resides in the fact that he takes into account the peculiar and interiorised trails of thought, and thus tries to think of appropriate productive and receptive relations that appreciably improve the viewer's interiority. It is in this sense that Stimmung can be associated with Riegl's concept of harmony since Stimmung seems to be rooted in the relationality of space-time, in order to have a soothing and mitigating effect against the transitory appearances of nature. The insistence on distant vision and the underlying causality of relations within the Stimmung is conceptualised on precisely this kind of interiority. And it is the capacity of art to engage with such interiority that forms the moral foundation of art and its specific contribution against the background of scientific reasoning.

\section{THE EVOLUTION OF THE SCIENTIFIC KUNSTWOLLEN}

In his Philosophy of Money (1900), published just one year after Riegl's essay, the German sociologist and philosopher Georg Simmel explained how the feeling of distance radically affects the aesthetic experience in modernity. Simmel reduces this feeling to a distant image (Fernbild) attained by "distancing from nature and the particular abstract experience of the urban life."52 In addition, according to Simmel these conditions of distancing are directly related to the sciences. Simmel does not believe that knowledge and the new optical means -such as the microscope and the telescope - help to bridge the gap between viewer and object. In a rather Schopenhauerian tone, he states that with science "every problem 
solved often throws more than a new one, and that coming closer to things often only show us how far they are still from us...." 53 and he concludes that from a subjective standpoint, the distance in thought between man and world was shorter during times when mythological representation predominated.

Riegl's reasoning in his essay against this kind of discussion unexpectedly prefigures several concerns regarding the aesthetic response to technology and science. Aby Warburg would later insist on the importance of distance, and he would make a virulent argument against science and technology in his essay on the Serpent Ritual, arguing that science and electric apparatuses, such as the telephone and the telegraph, would result in the annihilation of the symbolic realm and of the space for contemplation (Denkraum) through the narrowing of time and distance - even describing Benjamin Franklin and Wright Brothers as the destructors of the feeling of distance (Ferngefühl-Zerstörer). ${ }^{54}$

In a certain sense this kind of arguments seem to overlook that scientific imagery had also enriched the worlds between distant and close vision: on the one hand, astronomic lithography by Etienne Trouvelot and the foundation of astrophotography by Henry Draper had maximised distant vision; and on the other, Etienne-Jules Marey and Eadweard Muybridge's experiments with photography had revealed a rich world of close vision. It is a pity that Riegl failed to address the potential link between art and technical imagery.

Yet in Riegl's thought distance vision does not always involve a distanciation of the spectator since the Stimmung is at the same time ensuring a kind of immersion. Delimiting the casual and temporal factors of Stimmung, Riegl does not only insist on the formality of optic vision, but he also grasps a kind of active immersion, where thought and perception are entwined.

The preference of distant and optic vision has of course also been the subject of harsh criticism. Since Johann Gottfried Herder and Denis Diderot down to Marshall McLuhan, 55 touch and proximity have been vastly re-appreciated in the field of aesthetics and phenomenology, whereas Walter Benjamin is usually credited for largely legitimising close vision for the technological age: "It is another nature which speaks to the camera as compared to the eye" is a phrase he will repeat ${ }^{56}$ and in a passage that seems to be a direct answer to Riegl's Stimmung Essay he explains that:

Details of structure, cellular tissue, with which technology and medicine are normally concerned - all this is, in its origins, 
more closely related to the camera than is the emotionally evocative landscape or the soulful portrait. Yet, at the same time photography reveals in this material physiognomic aspects, image worlds, which dwell in the smallest things .... 57

Miriam Hansen has noted that Benjamin's anti-auratic aesthetics may indeed play out as an inversion of Riegl's arguments on Stimmung, ${ }^{58}$ and Benjamin's argumentation in his essay "The Work of Art in the Age of its Technological Reproducibility” has been a direct attempt to revert contemplative aesthetics into habit and distraction (Zerstreuung).

In the last decades, this shift from the optical to the tactile has been developed through a wide area of scholarship for art and media that insists on embodied and affective spectatorship. Laura Marks and Mark B.N. Hansen ${ }^{59}$ have dealt with this issue in a more comprehensive manner describing the modalities of touch in different media. Now it would be tempting here to regard this shift as Benjamin - or even more radically as Marshall McLuhan - did, namely as privileging the tactile over the optic. Yet the philosophical foundations of this new scholarship on affective and embodied phenomenology were more concisely laid by Gilles Deleuze and Félix Guattari who, as Marks points out, "do not understand haptic and optical to be a dichotomy but insist that they slide into another." 60 Indeed when conceptualising their differentiation of striated and smooth space, Deleuze and Guattari acknowledge their debt to Riegl for the concepts of "close visionhaptic space", although they also point out that they are "making free use of these notions" without any criteria set from Riegl.61 Moreover Deleuze in his work on Bacon, uses the concepts of diagram and catastrophe in order to explain how Bacon surpassed "the duality of the optic and the tactile" and not in order to privilege one or another. 62

Riegl's essay on Stimmung is much closer to this kind of discussion. Firstly, it has the merit of addressing a rather embodied and active spectatorship. It is not about a tactility that is solely linked to formal and stylistic analysis as in his later works. Secondly, Riegl does not seem to consider tactility as a problematic approach to art, but he rather suggested that it corresponds to different nodes of perception and art and thus to a different Kunstwollen. Indeed Riegl should not be considered as a strict apologist of contemplative aesthetics, but rather as someone that inserted a permanent link of art's evolution to the senses. From the point of view of Riegl, the recent focus on tactility should not be situated within a static 
problem of contemplation vs. embodiment, but within the means that art uses in order to represent perceptual and cognitive shifts. This is also evident by the fact that Stimmung, as noted above, is specifically interwoven with cognitive, spatial and temporal elements that are variously affecting spectatorship.

In this respect, Riegl's arguments should not be considered devoid of concerns with affected spectatorship but rather as striving not to reduce affectivity into reflexivity. Although he still seems close to Hegel's historical treatment of art, he must also have been aware that after Hegel's thesis about the post-history and the arbitrary character of modern art (the so called "End of Art" thesis), ${ }^{63}$ the continuation of these developments is by no means self-evident. Seeking the Kunstwollen of the age of the natural sciences can be considered largely responsive to this thesis and here the Stimmung Essay exemplifies Riegl's attempt to redefine the status of art within the increasingly sovereign scientific worldview.

So Riegl's essay can be read as an attempt to synthesise the tradition of Hegel, which influenced art history more directly, and the one of Kant (probably in its Herbartian filiation) which was central for applied aesthetics. As in Hegel, the greater schema of the essay is clearly based on the confluences of mind and art but at the same it is more grounded in the senses and their age-specific objectifications. Riegl's thinking should thus logically urge us to re-examine the Kunstwollen and to address art's role in every new configuration, even after the paradigm of Newtonian space and of the Classical world view came to its final end in the twentieth century. In this sense, Riegl's attempt to seek a Kunstwollen for the scientific age should not lead to mere rationalisation of perception nor be limited to thematic artworks, as often happens in new media art or digital art. It has to do with a rather triangle and complex relationship of art with cognition and affects, whose resulting issue could be to further investigate the correlations of today's scientific reasoning with aesthetics and even to seek the cognitive reconfigurations of tactile and optical vision. And hopefully this could also become an issue which may help to further bridge art and science. 
1 Martin Kemp, Structural Intuitions: Seeing Shapes in Art and Science (Charlottesville, VA: The University of Virginia Press, 2016); Martin Kemp, Seen/Unseen: Art, Science and Intuition from Leonardo to Hubble Telescope (Oxford: Oxford University Press, 2006).

2 Alois Riegl, "Die Stimmung als Inhalt der modernen Kunst," Die graphischen Künste, no. 22 (1899): 47-56. (Reprinted without images in Alois Riegl, Gesammelte Aufsätze (Berlin: Gebr. Mann, 1995), 28-39). Further citations of the essay, including a short discussion of its images, will be from the original publication. In order to avoid the long title, it will be referred to as the Stimmung Essay. Translations of excerpts are by the author of this article.

3 Notable exceptions are Margaret Olin, Forms of Representation in Alois Riegl's Theory of Art (University Park, PA: Pennsylvania State University Press, 1992), 124-127; Adi Efal, "Reality as the Cause of Art: Riegl and the Neo-Kantianism," Journal of Art Historiography, no. 3 (2010); Marsha Morton, “Art's 'Contest With Nature': Darwin, Haeckel and the Scientific Art History of Alois Riegl," in Darwin and Theories of Aesthetics and Cultural History, ed. B. Lason and S. Flach (Farnham: Ashgate, 2013), 53-69.

4 Riegl was not as implicated as Franz Wickhoff in the debate, cf. Carl Schorske, Fin-de-siècle Vienna: Politics and Culture (New York: Vintage, 1981), 231-236. Yet this essay was Riegl's main exposé for his views on the general character of modern art. For an analysis of the essay in specific correlation to its historic context, see: Diane Reynolds Cordileone, Alois Riegl in Vienna 18751905: An Institutional Biography (Farnham: Ashgate, 2014), 207-213.

5 See Leo Spitzer, Classical and Christian Ideas of World Harmony: Prolegomena to an Interpretation of the Word 'Stimmung' (Baltimore: John Hopkins Press, 1963); David Wellbery, "Stimmung," in Ästhetische Grundbegriffe, vol. 5, ed. by K. Barck (Stuttgart: Metzler, 2003), 703-733 and Hans Ulrich Gumbrecht, Atmosphere, Stimmung, Stimmung: On a Hidden Potential of Literature, trans. by E. Butler (Stanford, CA: Stanford University Press, 2011), 3-12. Stimmung can be translated as ambience, atmosphere, mood,

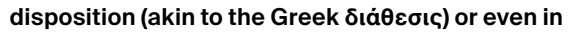
Heidegger, as attunement. This article will keep the original German word Stimmung in order to avoid any connotations that are foreign to Riegl's text.

6 Margaret Olin has provided an analysis of the general role it plays in Riegl's approach to the arts. See Margaret Olin, "Forms of Respect: Alois Riegl's Concept of Attentiveness," Art Bulletin 71, no. 2, (1989): 285-299 and Margaret Olin, Forms of Representation, 122-127.

7 Margaret Iversen has shown that this distinction is made by Adolf Hildenbrand in his book The Problem of Form in Visual Art (Das Problem der Form in der bildenden Kunst), published in 1893. Furthermore, it is clearly embedded in a "post-Herbartian psychology of perception" which proved influential for early art historiography; see Margeret Iversen, Alois Riegl: Art History and Theory (Cambridge, MA: MIT Press, 1993), 73-76. It should be noted that here Riegl does not use in this essay the term haptic (haptisch), a term which appears in his later work.

8 "rastlosen Lebens, unendlicher Kraft, und unaufhörlicher Bewegung"-“vereinigende Ruhe," Riegl, "Die Stimmung als Inhalt der modernen Kunst," 47.

9 "Was nun die Seele der modernen Mensch bewußt oder unbewußt ersehnt, das erfüllt sich dem einsam Schauenden auf jenes Bergeshöhe. Es ist nicht der Friede des Kirchhofes, der ihn umgibt, tausendfältiges Leben sieht er ja sprießen; aber was in der Nähe erbarmungsloser Kampf, erscheint ihm aus der Ferne friedliches Nebeneinander, Eintracht, Harmonie. [...] Diese Ahnung aber der Ordnung und Gesetzlichkeit über dem Chaos, der Harmonie über den Dissonanzen, der Ruhe über den Bewegungen nennen wir die Stimmung. Ihre Element sind Ruhe und Fernsicht." Ibid., 48 (emphasis in this article).

10 "ins Kampf um Dasein zurückgeschleudert." Ibid.

11 Ibid., 48-49.

12 David Parisi, "Tactile Modernity: On the Rationalization of Touch in the Nineteenth Century," in Media, Technology and Literature in the Nineteenth Century, ed. by C. Colligan and M. Linley (Farnham: Ashgate, 2011), 189-213.

13 "Das Drückende entspringt vom unserem Wissen, der reifen Frucht vom Baume der Erkenntnis." Riegl, "Die Stimmung als Inhalt der modernen Kunst," 49.

14 "das klare Spiegelbild des Weltgetriebes in der Nahsicht." lbid.

15 Arthur Schopenhauer, The World as Will and Representation, vol. I, ed. and trans. by J. Norman, A. Welchman and C. Janaway (Cambridge University Press: Cambridge, 2010), 224. Iversen has also commented on the possible influence of Schopenhauer on Riegl's work on the Dutch Group Portrait, see Iversen, Alois Riegl, 97-98.

16 The following passage is indicative of this affinity of Schopenhauer's sublime theory and the Stimmung essay by Riegl: "Because opposites shed light on each other, we should perhaps remark here that the true opposite of the sublime will certainly not be recognised as such at first glance: it is the stimulating [das Reizende]. I understand by this something that arouses the Will with the prospect of immediate satisfaction, fulfillment. If the feeling of the sublime comes about when something directly unfavourable to the Will becomes an object of pure contemplation, and this contemplation is sustained only by constantly turning away from the Will and rising above its interests, this constituting the sublimity [Erhabenheit] of the disposition [Stimmung], the stimulating by contrast drags the viewer down from the pure contemplation required for any contemplation of the beautiful, since it necessarily stimulates his Will with the same immediately agreeable objects, so that the viewer no longer remains the pure subject of cognition but instead turns into the needy, dependent subject of willing." Arthur Schopenhauer, The World as Will and Representation, 232. The link of Stimmung to the aesthetics of the sublime was already evident in the eighteenth century, notably in Kant's Third Critique, and became commonplace in the nineteenth century.

17 Schopenhauer, The World as Will and Representation, 208. 
18 "Wie unser modernes Wissen die Naturerscheinungen nicht mehr in ihrer Vereinzelung betrachtet, wie die heidnische Antike und das christliche Mittelalter gethan hat - als individuelle Äußerungen einer persönlichen Gottheit - sondern als kausale Zusammenhange mit ihrer näheren und entfernteren Umgebung: ebenso verfährt die moderne Kunst in der Aufnahme jener Natureindrücke, über die sie nicht hinaus kann, die sie aber mit ihren eigenartigen Mittel wiederschafft. So begreift sich vor Allem, daß das moderne Stimmungsbedürfnis voll und unmittelbar nur durch die reinen optischen Aufnahme beruhende und daher von Haus aus fernsichtige Malerei gestillt und befriedigt werden kann." Riegl, "Die Stimmung als Inhalt der modernen Kunst," 52.

19 Ibid, 49-51.

20 The pictures come from the painters Sion Wenban, Carlos Grethe, Karl Pippich, Max Liebermann and Carel Storm van's Gravensande. Only the last two are named in the article's text.

21 "aber wohl und dahin überzeugen, daß dieselbe, wenn sie existierten, so und nicht anders aussehen and sich gehaben müßte," Riegl, "Die Stimmung als Inhalt der modernen Kunst," 54.

22 Georg W. F. Hegel, Aesthetics: Lectures on Fine Art, vol. I, trans. by T. M. Knox (Oxford: Clarendon Press, 1975), 29.

23 As Carus explains: "When we look at nature or at a work of art we apprehend objects as notions in that we refer to them in our own consciousness; and yet, at the same time, because in the process the ego is itself referred to a new aspect of the external world (that is, put into a different state), a feeling must also arise, which will be homogeneous with the Stimmung that either manifests itself through individual phenomena in the life of nature or corresponds to the feeling from which, as from an inner unity, first the notion and then the physical form of the work arose"; Carl Gustav Carus, "Enclosure I to the Third Letter: On the Correspondences between Mental Stimmungs and Natural States," in Nine Letters on Landscape Painting, trans. by D. Britt (Los Angeles: Getty Research Institute, 2002), 92.

24 Carus, Nine Letters on Landscape Painting, 38.

25 Alexander von Humboldt, Cosmos: A Sketch of a Physical Description of the Universe, vol. I, trans. by E. O. Otté (Baltimore and London: John Hopkins University Press, 1997), 39-40.

26 Humboldt, Cosmos, vol. II, 82-98.

27 Alois Riegl, Historische Grammatik der bildende Künste, ed. by O. Pächt et K. Swoboda (Graz and Cologne: Böhlau, 1966); Alois Riegl, Historical Grammar of the Visual Arts, trans. by Jacqueline E. Jung, introduction by B. Stock, (New York: Zone Books, 2004).

28 Riegl, Historical Grammar, 137.

29 Wilhelm Worringer, Abstration and Empathy. A Contribution to the Psychology of Style, trans. by M. Bullock (Chicago: Elephant, 1997).

30 Riegl, Historical Grammar, 339.

31 As he explains in a note of Historical Grammar: "Art and philosophy do not coincide the way art and religion do, which both create harmony for mankind. Philosophy always runs slightly ahead being critical; it does not create harmony but rather destroys it. It is certainly capable of creating harmony - but only at a later point when its lessons have become common property." Riegl, Historical Grammar, 442.

32 Erwin Panofsky, "The Concept of Artistic Volition (1920)", trans. by Kennth Northcott and Joel Snyder, Critical Inquiry 8, no.1 (1981): 17-33.

33 Alois Riegl, "Das Moderne in der Kunst," Mitteilungen der Gesellschaft für vervielfältigende Kunst 2, 1899: 9-12; Julius Lessing, Das Moderne in der Kunst: Vortrage gehalten in der Volkswirtschaftlichen Gesellschaft zu Berlin, no. 157 of the series Volkswirtschaftliche Zeitfrage, Berlin: Simion, no. 1898. It is largely an expansion of Lessing's better known article, "Neue Wege," cf. Julius Lessing, "Neue Wege," Kunstgewerbeblatt 6 (new series), no. 1 (1895): 1-5.

34 "mit der Überzeugung von der unbedingten Geltung der Casualität" - "einer ganzen Ketten von Ursachen und Wirkungen, die wir gleichsam aus der Ferne überschauen," Riegl, “Das moderne in der Kunst," 10.

35 Ibid., 11.

36 "die jetzt ebenso volksthümlich geworden ist, als in Alterthum die tastbare-materielle Plastik gewesen war," Ibid., 12.

37 Ibid., 55.

38 "stand hier dem vollen Durchbruche der Stimmungskunst nichts mehr im Wege," lbid.

39 "aus dem vorhanden Vorrath an Kunstdenkmälern früherer Jahrhunderte alles dasjenige heranzuziehen, was dem mehr oder minder klar empfundene Stimmungsbedürfnisse entsprechend scheinen konnte" - "die venezianische Existenzmalerei." lbid.

40 Ibid.

41 "geistig tief erregten Zeit,", Ibid., 56.

42 “...den letzten, höchsten, entscheidende Gewinn aus dem modernen Wissen ziehen und damit dem trostbedürftigen Zeitgeschlecht Erleichterung, wo nicht Erlösung bringen," lbid.

43 Olin, Forms of Representations, 126.

44 Alois Riegl, "Das Riesenthor zu St Stephan," Neue Freie Presse, 1 Feb. 1902, 3.

45 Translated by Kurt W. Foster and Dian Ghirardo in Alois Riegl, "The Modern Cult of Monuments: Its Character and Its Origin," Oppositions: Journal for Ideas and Critisism in Architecture, no. 25, Fall 1982, 21-51.

46 Riegl, "The Modern Cult of Monuments," 24.

47 Ibid., 31 (translation slightly modified).

48 Ibid., 32.

49 Ibid., 31.

50 The original text in German is "um dem modernen Stimmungsmenschen vollkommene Erlösung zu verschaffen" here quoted from Alois Riegl, "Das moderne Denkmalkultus: sein Wesen und seine Entstehung," in Riegl, Gesammelte Aufsätze.

51 Riegl, "The Modern Cult of Monuments," 34. For the repercussions of Riegl's views, cf. Bernd Euler-Rolle, "Der Stimmungswert in spätmoderne Denkmalkultus. Alois Riegl und die Folgen," Österreichische Zeitschrift für Kunst und Denkmalpflege, no. 1, 2005, 27-34.

52 It is interesting to cite the whole passage which seems very close to the arguments in Riegl's Stimmung Essay: "If modern man finds his highest enjoyment in the snowbound regions of the Alps or on the shores of the 
North Sea, then this can hardly be explained solely in terms of the heightened need for excitement. It is also to be explained by the fact that this inaccessible world, which actually rejects us, represents the extreme enhancement and stylization of what nature as a whole still means to us: a spiritual distant image [Fernbild] that confronts us in moments of physical proximity [körperliche Nähe] as something internally unattainable, a promise that is never fully kept .... Landscape painting, which as an art depends upon distance from the object and upon a break in our natural unity with it, has only developed in the modern times as has the Romantic sense of nature. They are the result of that increasing distance from nature and that particularly abstract existence that urban life based on the money economy has forced upon us"; Georg Simmel, Philosophy of Money, trans. by T. Bottomore and D. Frisby (London: Routledge, 2004), 484. In addition, the link of landscape and Stimmung was already evident in Simmel's essay "Philosophy of Landscape" a few years after, cf. Georg Simmel, "Philosophy of Landscape" (1912), Theory, Culture \& Society 24, no. 7-8 (2007): 20-29. See also a similar passage in Simmel's early essay 'On Art Exhibitions' (1890): Georg Simmel, “On Art Exhibitions”, Theory, Culture \& Society 32, no. 1 (2015): 90.

53 Simmel, Philosophy of Money, 481.

54 Aby Warburg, Schlangenritual. Ein Reisebericht (Berlin: Wagenbach, 2011), 75.

55 Mark Paterson, The Senses of Touch: Haptics, Affect and Technologies (Oxford and New York: Berg, 2007).

56 Cf. Walter Benjamin, "The Work of Art in the Age of its Technological Reproducibility," in The Work of Art in the Age of its Technological Reproducibility and Other Writing on Media, ed. by M. Jenning, T. Levin and B. Doherty (Cambridge, MA: Harvard University Press, 2008), 37; and Walter Benjamin, "Little History of Photography," ibid., 277.

57 Ibid., 279.

58 Miriam B. Hansen, "Benjamin's Aura," Critical Inquiry 34 (2008): 336-375 (especially 352).

59 See Mark B. N. Hansen, New Philosophy for New Media (Cambridge, MA: MIT Press, 2004); Laura Marks, Touch: Sensuous Theory and Multi-Sensory Media (Minneapolis, MI: University of Minnesota Press, 2002).

60 Marks, Touch, xii.

61 Gilles Deleuze and Félix Guattari, $A$ Thousand Plateaus: Capitalism and Schizophrenia II, trans.by B. Massumi (Minneapolis: University of Minnesota Press, 1987), 493. For the "Smooth and the Striated" see the homonymous chapter, 471-500. They also reference to Worringer and the French philosopher and art theorist Henri Maldiney.

62 Gilles Deleuze, Francis Bacon: The Logic of Sensation, trans. by D. Smith (London and New York: Continuum, 2003), 161.

63 See Hegel, Aesthetics,vol. I, 604-608. 